\title{
2. EXPLANATORY NOTES AND SHIPBOARD PROCEDURES, DEEP SEA DRILLING PROJECT LEG 50
}

\author{
The Shipboard Scientific Party ${ }^{1}$
}

Standard procedures for both drilling operation and preliminary shipboard analysis of the material recovered have been regularly amended and upgraded in the course of the last 10 years of deep-sea drilling. In this chapter, we assembled information that could help the reader understand the basis for our preliminary conclusions, and help the interested investigator select samples for further analysis. This information regards only shipboard operations and analyses described in the site reports. The reader is referred to individual scientific contributions for more details on methods used by various investigators for further shore-based analysis of data accumulated during Leg 50.

\section{AUTHORSHIP OF SITE REPORTS}

Authorship of the two site reports is shared among the entire shipboard scientific party, although the two co-chief scientists edited and rewrote part of the material prepared by other individuals. The site chapters are organized as follows (authorship in parentheses):

Site Data and Principal Results (Lancelot, Winterer)

Background and Objectives (Lancelot, Winterer)

Operations (Lancelot, Winterer)

Lithology (Bosellini, Lancelot, Melguen, Price, Schlager, Winterer)

Biostratigraphy

Biostratigraphic Summary (Čepek, Sliter, Vincent, Westberg)

Foraminifers (Sliter and Vincent)

\footnotetext{
${ }^{1}$ Yves Lancelot (Co-Chief Scientist), Departement de Géologie Dynamique, Université Pierre et Marie Curie, Paris, France; Edward L. Winterer (Co-Chief Scientist), Geological Research Division, Scripps Institution of Oceanography, La Jolla, California; Alfonso Bosellini, Geological Institute, University of Ferrara, Ferrara, Italy; Georges A. Boutefeu, Pétrofina Exploration, Brussels, Belgium (Present address: Petrangol, CP 1320, Luanda, Republic of Angola); R. E. Boyce, Deep Sea Drilling Project, Scripps Institution of Oceanography, La Jolla, California; Pavel Čepek, Bundesanstalt für Geowissenschaften und Rohstoffe, Hannover, Federal Republic of Germany; Duane Fritz, Gulf Energies and Minerals International, Houston, Texas; Eric M. Galimov, V. I. Vernadsky Institute of Geochemistry and Analytical Chemistry, U.S.S.R. Academy of Sciences, Moscow, U.S.S.R.; Marthe Melguen, Centre Océanologique de Bretagne, Brest, France; Ilfryn Price, The British Petroleum Company, Ltd., London, England; Wolfgang Schlager, Rosenstiel School of Marine and Atmospheric Science, Miami, Florida; William Sliter, U.S. Geological Survey, Paleontology and Stratigraphy Branch, Menlo Park, California; Kazuo Taguchi, Institute of Mineralogy, Petrology, and Economic Geology, Tohoku University, Sendai. Japan; Edith Vincent, Geological Research Division, Scripps Institution of Oceanography, La Jolla, California; and Jean Westberg, Geological Research Division, Scripps Institution of Oceanography, La Jolla, California.
}

Nannofossils (Čepek)

Radiolarians (Westberg)

Physical Properties and Well-Logging Measurements (Boyce)

Organic Geochemistry (Boutefeu, Galimov, Taguchi)

Rate of Sedimentation (Čepek, Lancelot, Sliter, Vincent, Winterer)

Correlation of Seismic-Reflection Profiles with Drilling and Logging Results (Winterer)

JOIDES Safety and Pollution-Prevention Program

(Fritz)

Summary and Conclusions (Lancelot, Winterer)

Following the text are graphic lithologic and biostratigraphic logs of each core, and photographs of each core.

\section{SURVEY AND DRILLING DATA}

Seismic-reflection data in the vicinity of the two drill sites are included in the site reports. Profiler records and magnetometer data between the drill sites, and on the tracks to and from the port of Funchal, are given in the chapter on underway geophysics, along with a multichannel record run by the Deutches Bundesanstalt für Geowissenschaften und Rohstoffe and made available by Dr. Karl Hinz.

The ship's track is satellite-navigated, and the location of drill sites is the mean of repeated (about 10) satellite positions taken while the ship was at the drill site positioned over the acoustic beacon.

The seismic profiling system used on Glomar Challenger comprised two 40 -in ${ }^{3}$ Bolt airguns, a Scripps-designed hydrophone array, Bolt amplifiers, two bandpass filters, and two EDO dry paper recorders, generally operating at different sweep rates and filter settings.

The depth of water at the drill site is the depth measured with the Gifft Precision Graphic Recorder (PGR), assuming a sound velocity of 800 fathoms/s, corrected according to Matthews (1939) tables. Further corrections are made for the depth of hull-mounted sound transducer below the water line of the vessel $(6 \mathrm{~m})$. When pipe lengths are measured from the derrick floor, a correction of 10 meters is applied for the height of the floor above the waterline.

The depth at any level below the sea floor is the difference between the length of pipe to reach the sea floor and the length to the level in question, a simple enough calculation; however, because of the presence of socalled bumper-subs (a kind of splined shock absorber in the bottom-hole assembly) the pipe can be telescoped about 3 meters simply by increasing the weight on the bit. There is thus a small uncertainty in all these depth measurements. 


\section{DRILLING CHARACTERISTICS}

The rate of drilling in firm sediments and in rocks is a rough measure of the degree of induration of the strata, and we therefore kept a log of that rate in minutes per meter of penetration. The drilling rate is of course also affected by rate of rotation of the bit, the weight on the bit, the type of bit used, the rate of circulation of drilling fluid (sea water), the state of the sea, and doubtless several other factors as well; nonetheless, it can be a help in picking out lithologic breaks where core recover is scanty.

The drilling process commonly results in a mechanical disturbance of the cored material, by distorting bedding, producing fractures, and injecting water. The result ranges from only the slightest turndown of strata at the edges of the core to a homogenous drilling paste with the consistency of a malted milk shake. Soft or easily fractured layers are commonly washed out entirely. Before ordering samples of the cores, special care should be taken to study both the lithologic log of the core, which shows graphically the degree of disturbance, and the core photographs at the end of the site chapter.

Symbols used on the core-description sheets to denote core disturbance are as follows:

$$
\begin{array}{ll}
----- & \text { slight } \\
---- & \text { moderate } \\
\text { manm } & \text { very deformed } \\
\text { soupy }
\end{array}
$$

In drilling with only sea water as the fluid circulates down the drill pipe and up the annulus around the pipe, there is no effective way to prevent washing-out and caving-in of weak materials from the walls of the hole. The diameter of the hole is thus very uneven, and probably includes some very wide places in softer sediments. Aside from the operational problems this poses (e.g., drill cuttings tend to lodge in the recesses instead of being circulated back to the sea floor), the uneven hole diameter poses a serious difficulty in interpreting the down-hole logs. On Leg 50, the caliper log would not operate, and we thus have no control on the hole diameter.

\section{GENERAL SHIPBOARD SCIENTIFIC PROCEDURES}

DSDP drill sites are assigned numbers as part of the consecutive sequence that started with the first site drilled by Glomar Challenger in 1968. A site comprises all holes drilled while the vessel is positioned over a single acoustic beacon; thus, several holes can be drilled at a site. The first hole drilled at a site is given the site number (e.g., Hole 415); the next hole is labeled Hole 415A, the next Hole 415B, etc.

The cored interval is measured in meters below the sea floor. The depth interval of an individual core is the depth below sea floor where the coring operation began to the depth where the coring operation ended. Each coring interval is generally 9.5 meters long, which is the nominal length of a core barrel; however, the coring in- terval may be shorter or longer (rare). Cored intervals are not necessarily adjacent to each other, but may be separated by drilled intervals. In soft sediment, the drill string can be washed ahead with the core barrel in place, but not recovering sediment, by pumping water down the pipe at high pressure to wash the sediment out of the way of the bit and up the space between the drill pipe and wall of the hole; however, if thin, hard rock layers are present it is possible to get spotty sampling of these resistant layers within the washed interval, and thus have a cored interval greater than 9.5 meters. We cored particularly long intervals in Hole 415A for Cores 6 and 15, and in Hole 415A for Cores 7, 8, and 35. In drilling hard rock, a center bit may replace the core barrel if it is necessary to drill without core recovery.

Cores from each hole are numbered consecutively. When a new hole is begun, a new core sequence is begun. A core is assigned its number even if no material was recovered. The plastic liner in the core barrel is 9.3 meters long, but there is an additional 0.2 meters of core catcher below; the nominal coring interval is thus 9.5 meters. Of course, shorter cores can also be taken.

When the core barrel is retrieved on deck, the core catcher is removed to the laboratory and the core liner is cut up into numbered sections, each a maximum of 1.5 meters in length. A completely full liner 9.3 meters long is cut into six 1.5 meter sections, numbered Sections 1 through 6 , starting from the top, plus a 0.3 meter section at the bottom, which is labeled core-catcher (CC) along with the actual catcher sample. When the core recovery is less than 100 per cent, the sections are cut by starting Section 1 at the top of the sediment, and proceeding down with successive 1.5 meter sections, with a short section at the bottom, above the core catcher. Cores with voids are generally cut so as to preserve the void space in the same position as when the core was brought on deck. Figure 1 shows diagrammatically the section numbering system.

By convention, the depth assigned to the top of Section 1 of a core is the depth to the top of the cored interval. The missing material in partly filled barrels is thus assigned to the lower part of the cored interval. This convention can create problems in interpretation of the cores, because the assigned positions of core sections may be very different from their real positions. Consider two consecutive cores, the upper of which recovered only a core catcher sample: it is by convention placed 9.5 meters above the top of the lower core, whereas it may in reality have been immediately above. Zonal thicknesses, rates of accumulation, chemical gradients - all sorts of calculations can be affected by this convention.

When the cores have been removed to the shipboard laboratory, and after certain routine measurements have been made on them, they are split in half lengthwise. One half is designated the archive half, and the other the working half. The archive half is examined visually and described, but only tiny smear slide samples are removed for study. This half is photographed in black and white and in color. The working half is sam- 


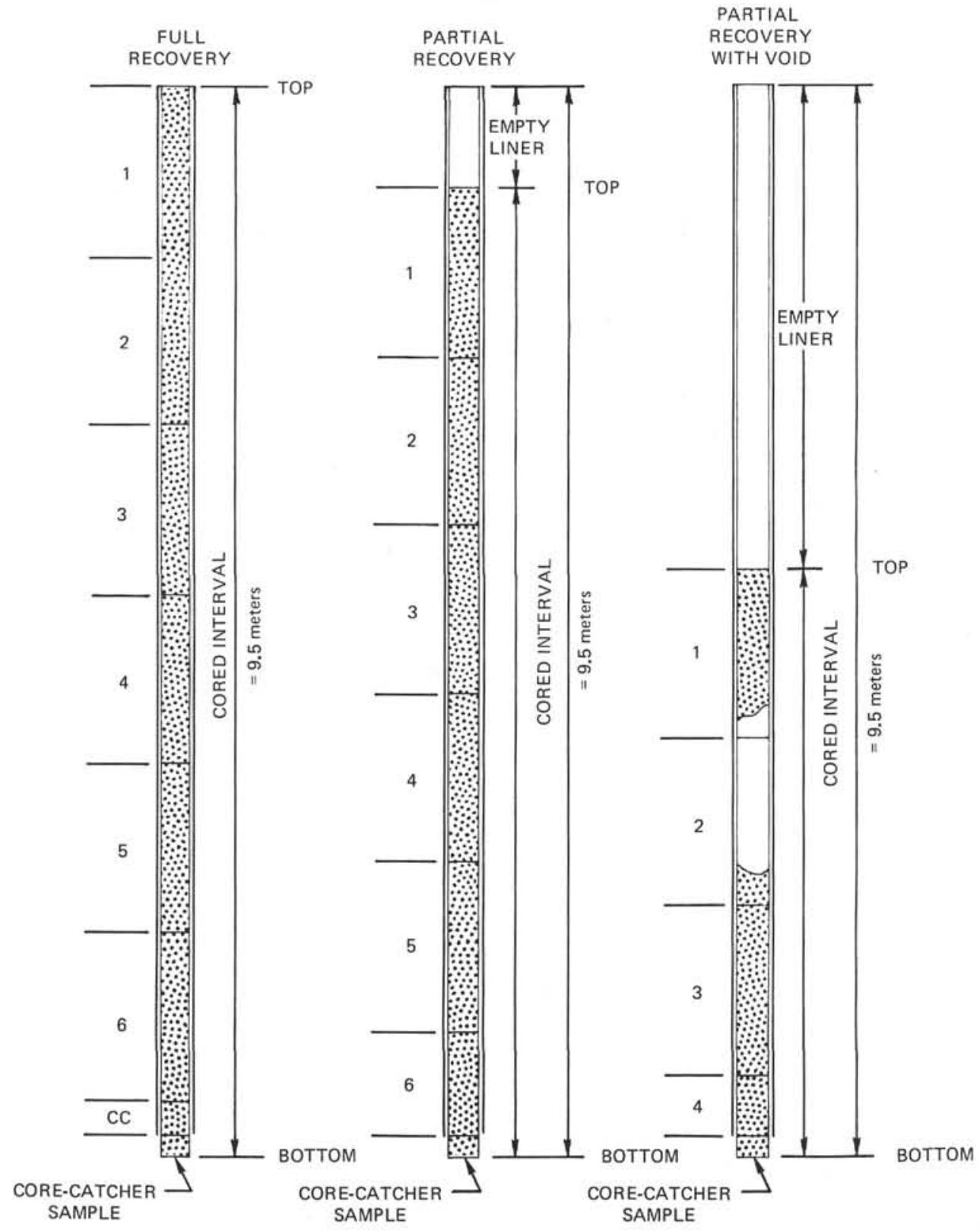

Figure 1. Diagram showing procedure in cutting and labeling of core sections.

pled, not only for the various shipboard studies, but also for shore-based studies by the shipboard scientists and by others whose sampling requests have been approved.

With one exception, only a part of the core at any stratigraphic level can be removed from the working half, so as to leave something for future work. The exception is the set of samples taken for archiving for future shore-based studies on organic geochemistry. At certain intervals, a $50-\mathrm{cm}$-long section is cut from the full core liner, before it is cut in half lengthwise. This sample is then frozen and sent back to the core-curating facility at the Scripps Institution of Oceanography.

Within a core section, samples are designated by the interval in centimeters, measured from the top of the section. The full designation of a sample is a sequence of numbers giving the number of the drilling leg (50), hole, core, section, and the interval of the sample in the section. For example, 50-416A-37-2, 20-22 cm designates a sample taken from the interval 20 to $22 \mathrm{~cm}$ below the top of Section 2 in Core 37 from the second hole drilled at Site 416 on Leg 50. The depth below the sea floor of this sample is the depth to the top of the cored interval plus 1.50 meters (the length of Section 1) plus 20 $\mathrm{cm}$ (depth below the top of Section 2). A core-catcher sample from this core would be labeled 50-416A-37, CC.

In requesting samples from Leg 50 cores, the user should take care to examine the graphic logs of the individual cores and the core photographs in the site chapters, and to specify carefully the lithology of the interval which includes the desired sample. This is because the core material may have shifted in the core liner during 
the time since the original shipboard measurements were made.

\section{CORE HANDLING}

Generally, as soon as a core is retrieved on deck, a sample is taken from the core catcher and taken to the paleontological laboratory for an initial assessment of the age of the sample.

The core is then placed on a long horizontal rack and gas samples are taken by piercing the core liner and withdrawing gas into a vacuum-tube sampler. Voids within the core are sought as sites for the gas sampling. Some of the gas samples are stored for shore-based study, but some are analyzed immediately, as part of the safety and pollution-prevention program. Next, the core is marked into section lengths, each section is labeled, and the core is cut into sections. Each section is sealed top and bottom by gluing on a plastic cap. From some cores, tiny smear-slide samples may be taken from the section ends before capping.

The cores are then carried into the laboratory, where the sections are again labeled, using an electric branding iron to burn in the full designation of the section. The length of core in each section and in the core-catcher sample is measured to the nearest centimeter, and this information is logged.

The cores are then allowed to warm to room temperature before making further measurements. During this time (generally about 12 hours), additional gas samples may be extracted.

After the cores have come to room temperature, the sections are run through the GRAPE (gamma-ray-attenuation porosity evaluation) device for estimating bulk density and porosity (Boyce, 1976).

Cores of relatively soft material are then split lengthwise into the working and archive halves. The softer cores are split with a wire or coping saw, depending on the degree of induration. In soft sediments, some smearing of material can occur, and to minimize contamination users of the cores should avoid using the very nearsurface part of the split core. Harder cores may be split with a band saw, or even with a diamond saw. Where the cored material is of uneven diameter, or does not have the diameter of the core liner, the diameter of the opened but unsplit core is measured with calipers at all significant points to provide the path-length data needed to interpret the GRAPE data.

The working half is then sampled for both shipboard and shore-based laboratory studies. Each extracted sample is logged by location, purpose of sample (e.g., mineralogy), and (or) the name of the investigator receiving the sample. Records of all removed samples are kept by the curator at DSDP in La Jolla, for samples taken aboard ship and those taken after the cores are returned to the archiving facility. The extracted samples are sealed in plastic vials or bags and labeled. Samples were routinely taken for grain-size distribution, mineralogy by X-ray diffraction, sonic velocity by the Hamilton Frame method as described in Boyce (1976), wetbulk density by a static GRAPE technique (Boyce, 1976), water content by gravimetric analysis, carbon- carbonate analysis, per cent calcium carbonate (Carbonate bomb), geochemical analysis, paleontological studies, and other purposes. The carbon-carbonate data are reported in an appendix to this volume, and the water content (bulk density) is reported in the site chapters.

The archive half is described visually, and smear-slide samples are supplemented by thin sections and acetate peels taken from the working half and studied under the petrographic microscope. This half is then photographed in both black and white and color, a whole core at a time.

Both halves are then put into labeled plastic tubes, sealed with masking tape, and transferred to cold-storage space aboard the drilling vessel. The core-catcher samples are stored in smaller sealed and labeled plastic containers. Leg 50 cores were transferred from the ship via refrigerated vans to cold storage at the East Coast Repository, at Lamont-Doherty Geological Observatory, Palisades, New York.

\section{LITHOLOGIC CLASSIFICATION}

The basic classification system used here was devised by the JOIDES Panel on Sedimentary Petrology and Physical Properties (SPPP) and adopted for use by the JOIDES Planning Committee in March, 1974. For the sake of continuity, the Leg 50 shipboard scientists have used this classification, with some slight modification. We will point out our departures from the classification where appropriate.

\section{General Principles}

This classification is not comprehensive; therefore, a category of "special rock types" will create additional definitions and terminology of rock types not covered. The classification is descriptive, and genetic implications are not intended. These divisions are naturally artificial, and the proposed classification is only a rough scheme of what we find in nature. The classification, as used in this volume, will use data primarily estimated or measured aboard the ship.

\section{Descriptive Data}

Sediment and rock names are defined solely by composition and texture. Composition is most important for description of those deposits more characteristic of open-water marine conditions, texture becoming more important for the classification of hemipelagic and near-shore facies. These data are primarily determined aboard the ship by (1) visual estimates "in smear slides" with the aid of a microscope, (2) visual observation using a hand lense, and (3) simple unaided visual observations. Calcium-carbonate content was estimated in smear slides, by using the carbonate bomb technique, or the Leco WR-12 (DSDP shore-based laboratory) technique. Textures were primarily estimated in smear slides: only six grain-size samples were processed through the DSDP laboratory. Other determined geologic features are color, sedimentary structures, and firmness.

We use three classes of firmness for biogenic calcareous rocks which have a calcium carbonate content greater than 60 per cent, and only two classes of firmness for 
all other lithologies. Criteria for classes of firmness are those of Gealy et al., (1971):

1. Biogenic-calcareous sediments, with greater than 60 per cent $\mathrm{CaCO}_{3}$, have 3 classes of firmness:

A. Soft: Sediments which have little strength and are readily deformed under the finger or broad blade of the spatula are soft and are termed ooze.

B. Firm: Partly lithified ooze and friable limestone are called chalk. Chalks are readily deformed under the fingernail or the edge of a spatula blade. More-lithified chalks are termed limestones (see below).

C. Hard: Limestone is a term which is restricted to nonfriable cemented rock.

2. Only two classes of firmness are used for transitional carbonates with less than 60 per cent $\mathrm{CaCO}_{3}$, biogenic siliceous sediment, pelagic clay, and terrigenous sediments:

A. Soft: A sediment is soft if the sediment core may be split with a wire cutter. The following sediment terms are used for soft sediment:

i. Soft biogenic-siliceous sediments (with greater than 30 per cent siliceous fossils) are termed ooze (e.g., radiolarian ooze, diatom ooze, or siliceous ooze).

ii. Soft terrigenous sediment, pelagic clay, and transitional calcareous-biogenic sediments are termed as follows: sand, silt, clay, mud, or marl.

B. Hard: The core is hard if it must be cut with a band saw or diamond saw.

i. Hard siliceous-biogenic sediments (greater than $30 \%$ siliceous) are termed radiolarite, diatomite, chert, or porcellanite.

ii. Hard terrigenous sediment, transitional calcareous-biogenic sediment, and pelagic clay are termed as follows: a suffix -stone is added to the soft-sediment name (e.g., sandstone, siltstone, claystone, mudstone (shale, if fissile), or marlstone.

\section{Basic Sediment Types}

\section{Pelagic Clay}

Pelagic clays are principally authigenic pelagic deposits that accumulate at very slow rates. The class is often termed brown clay, or red clay, but because these terms are confusing they are not used.

1. The boundary of pelagic clay with terrigenous sediments is where authigenic components (Fe-Mn micronodules, zeolites, fish debris, etc.) become common $(>10 \%)$ in smear slides, indicating pelagic clay. The accumulation rates of pelagic clay and terrigenous sediments are very different; therefore, transitional deposits are exceptional.

2. The boundary of pelagic clay with siliceous-biogenic sediments is where there is less than 30 per cent siliceous remains.

3. The boundary of pelagic clay with calcareousbiogenic sediment is uncommon. Generally the facies passes from pelagic clay through siliceous ooze to calcareous ooze, with one important exception: at the base of many oceanic sections, black, brown, or red clays occur directly on basalt, overlain by or grading up into calcareous sediments. Most of the basal clayey sediments are rich in iron, manganese, and metallic trace elements. For proper identification, they require more-elaborate geochemical work than is available aboard ship. These sediments would be grouped as Special rock types.

\section{Pelagic-Siliceous-Biogenic Sediment}

Pelagic-siliceous-biogenic sediment is distinguished from pelagic clay because the siliceous-biogenic sediment has more than 30 per cent siliceous microfossils. Siliceous-biogenic sediments are distinguished from the calcareous category by a calcium-carbonate content of less than 30 per cent.

For a pelagic-biogenic-siliceous sediment with about 30 to 100 per cent siliceous fossils, the following terminology is used:

1. Soft: Siliceous ooze (radiolarian ooze, diatom ooze, etc., depending on the dominant fossil component).

2. Hard: Radiolarite, diatomite, chert, or porcellanite. The term "chert" in the past has been used in a very broad sense to designate almost any form of recrystallized silica. The term porcellanite (which has had very broad usage in the past) will be used here to refer to "low density, more or less porous and dull-lustered varieties of chert made of opaline silica or cristobalite . . ." (Lancelot, 1971). Chert used here will have a narrower scope than that of past usage, and will refer to "hard nodules and sometimes beds, that are largely quartz and/or chalcedony, and show a conchoidal fracture and a vitrous luster ..."' (Lancelot, 1973).

3. Compositional Qualifiers: Diatoms and radiolarians may be the principle components; thus, one or two qualifiers may be used, for example:

Indeterminate siliceous fossils: Siliceous ooze, chert, or porcellanite.

Radiolarians only: Radiolarian ooze, or radiolarite.

Diatoms only: Diatom ooze, or diatomite.

Diatoms < radiolarians: Diatom radiolarian ooze, or diatom radiolarite.

Diatoms > radiolarians: Radiolarian diatom ooze, or radiolarian diatomite.

The order of the two modifiers in the terms is dependent on the dominant fossil type. The most dominant component is listed last and the minor component is listed first.

Terminology for the pelagic clay transition with diatom sediments is as follows:

Biogenic

Siliceous

\begin{tabular}{|c|c|c|}
\hline $\begin{array}{c}\text { Fossil Particles } \\
\qquad(\%)\end{array}$ & $\begin{array}{l}\text { Clay } \\
(\%)\end{array}$ & Lithology \\
\hline$<10$ & $>90$ & $\begin{array}{l}\text { clay } \\
\text { claystone }\end{array}$ \\
\hline
\end{tabular}




$$
\begin{aligned}
& 30-10 \quad 70-90 \quad \text { diatom mud (soft) } \\
& 60-30 \quad 40-70 \quad \text { muddy diatom ooze (soft) } \\
& \begin{array}{lll}
100-60 & 0-40 & \begin{array}{l}
\text { muddy diatomite } \\
\text { diatom ooze } \\
\text { diatomite }
\end{array}
\end{array} \begin{array}{r}
\text { (hard) } \\
\text { (soft) } \\
\text { (hard) }
\end{array}
\end{aligned}
$$

Other terms may be substituted for the terms diatom and diatomite, respectively, as follows: (1) radiolarian and radiolarite if radiolarians are predominate, or (2) siliceous or chert if the fossil type is indeterminate.

We have divided the component frequencies into four major groups:

$$
\begin{array}{r}
<10 \% \\
10-30 \% \\
30-60 \% \\
>60 \%
\end{array}
$$

These boundaries have been used for both calcareous and siliceous components, and thus depart slightly from the SPPP classification, which employs only one major subdivision $(50 \%)$ in the biogenic siliceous sediments $(<50 \%$ siliceous fossils $=$ siliceous mud; $>50 \%$ siliceous fossils $=$ siliceous ooze). To be consistent we choose to subdivide both siliceous and calcareous pelagic facies in the same way.

\section{Pelagic-Biogenic-Calcareous Sediments}

Pelagic-calcareous sediments are distinguished by a biogenic $\mathrm{CaCO}_{3}$ content in excess of 30 per cent. There are two classes: (1) pelagic-biogenic-calcareous sediments, which contain 60 to 100 per cent biogenic $\mathrm{CaCO}_{3}$, and (2) transitional biogenic-calcareous sediments, which contain 30 to 60 per cent biogenic $\mathrm{CaCO}_{3}$.

1. For the pelagic-biogenic-calcareous sediment, with 60 to 100 per cent $\mathrm{CaCO}_{3}$, the following terminology is used:
A. Soft: Calcareous ooze.
B. Firm: Chalk.
C. Hard and cemented: Limestone.
C. Compositional qualifiers: If nannofossils and foraminifers are the principal components, then one or two qualifiers may be used, as in the following examples:

$\mathrm{i}$ Indeterminate carbonate fossils: Calcareous ooze, calcareous chalk, or calcareous limestone.

ii Foraminifers (0-10\%); nannofossils (90-100\%): nannofossil ooze, nannofossil chalk, or nannofossil limestone.

i i i Foraminifers (10-25\%); nannofossils $(75-90 \%)$ : foraminifer-nannofossil ooze, foraminifer-nannofossil chalk, or foraminifer-nannofossil limestone.

iv Foraminifers (25-50\%); nannofossils $(50-75 \%)$ : nannofossil-foraminifer ooze, nannofossil-foraminifer chalk, or nannofossil-foraminifer limestone.
2. The transitional biogenic-calcareous sediments, with 30 to 60 per cent $\mathrm{CaCO}_{3}$, are termed marl or marlstone, as follows:

A. Soft: Calcareous marl, foraminifer marl, or nannofossil marl.

B. Hard: Calcareous marlstone, foraminifer marlstone, or nannofossil marlstone.

Note: The use of the terms marl or marlstone differs from the SPPP classification. The panel's

\begin{tabular}{|c|c|c|}
\hline $\begin{array}{c}\text { Biogenic } \\
\text { Calcareous } \\
\text { Particles } \\
(\%)\end{array}$ & $\begin{array}{l}\text { Clay } \\
(\%)\end{array}$ & Lithology \\
\hline $0-10$ & $90-100$ & $\begin{array}{l}\text { clay } \\
\text { claystone }\end{array}$ \\
\hline $30-10$ & $70-90$ & $\begin{array}{l}\text { nannofossil mud } \\
\text { nannofossil mudstone }\end{array}$ \\
\hline $60-30$ & $40-70$ & $\begin{array}{l}\text { nannofossil marl } \\
\text { nannofossil marlstone }\end{array}$ \\
\hline $100-60$ & $0-10$ & $\begin{array}{l}\text { nannofossil ooze } \\
\text { nannofossil chalk } \\
\text { nannofossil limestone }\end{array}$ \\
\hline
\end{tabular}
classification used "marly" to modify ooze, chalk, or limestone (e.g., marly limestone), to denote sediments which had 30 to 60 per cent biogenic carbonate.

Terminology for the pelagic clay transition with the nannofossil sediments is as follows:

Other terms may be substituted for nannofossil, such as: (1) foraminifer, nannofossil-foraminifer, foraminifer-nannofossil, if foraminifers are present in the percentages as discussed; or (2) calcareous, if the fossil type is indeterminate.

\section{Terrigenous Sediment}

Terrigenous sediments are subdivided into textural groups on the basis of grain-size distribution (i.e., claysize, silt-size, and sand-size). Rocks coarser than sandsize are treated as "special rock types." The size limits of these constituents are defined by Wentworth (1922) (Figure 2).

Five major textural groups are recognized on the accompanying triangular diagram (Figure 3 ). These groups are defined according to the abundance of clay, and the ratio of sand to silt. The terms clay, mud, sandy mud, silt, and sand are used for soft sediment. The hard or unconsolidated equivalents for the same textural groups are claystone, mudstone (or shale, if fissile), sandy mudstone, siltstone, and sandstone.

Sands and sandstones may be subdivided further into very fine- $(0.0625-0.125 \mathrm{~mm})$, fine- $(0.125-0.25 \mathrm{~mm})$, medium- $(0.25-0.50 \mathrm{~mm})$, coarse- $(0.50-1.00 \mathrm{~mm})$, or very coarse-grained $(1.0-2.0 \mathrm{~mm})$ sands and sandstones according to their median grain size.

In this group, numerous qualifiers are possible, usually based on minor constituents, (e.g., glauconitic, pyritic, feldspathic). 


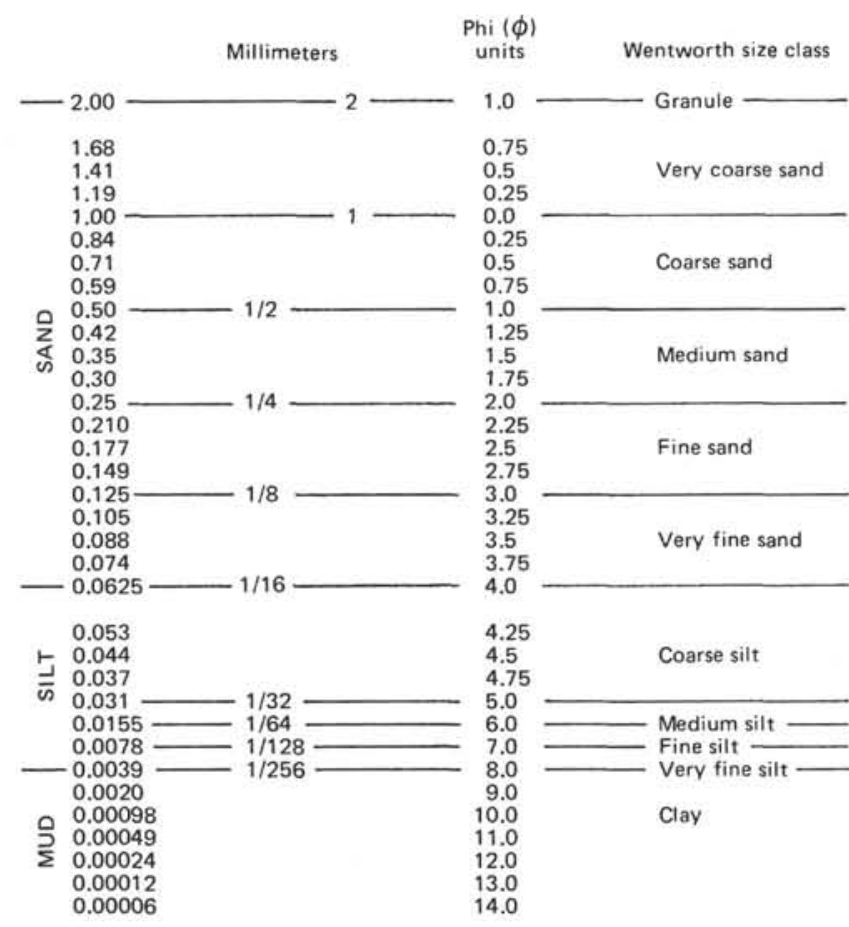

Figure 2. Terminology and class intervals for grade scales.

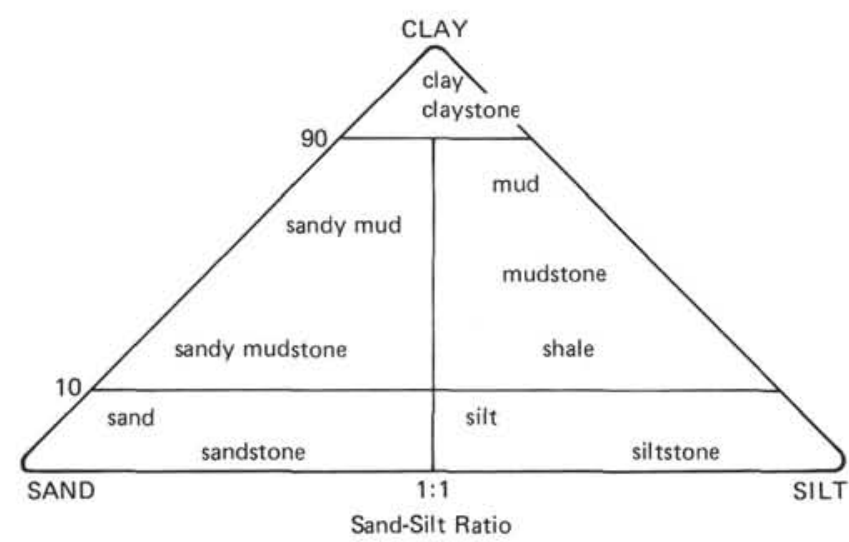

Figure 3. Textural groups for terrigenous sediments.

\section{Qualifiers}

In general, sediments containing various constituents in the range 10 to 30 per cent may be identified with the adjective "rich" (e.g., carbonate-rich, diatom-rich). Constituents which are in amounts of 5 to 10 per cent may be referred to by using the adjective "bearing" in the sediment name (this use of qualifiers differs from the SPPP classification.)

\section{Special Rock Types}

1. We desire to distinguish sandstones and siltstones made up predominantly of carbonate grains instead of quartz or lithic grains. Therefore, the following terms are used:

Calcarenite: Sandstone with predominantly carbonate grains.
Calcisiltite: Siltstone with predominantly carbonate grains.

2. Micritic limestones are those limestones whose grains are microcrystalline calcite.

3. Coquina is a porous limestone or chalk composed of broken shells, corals, and other biogenic debris.

4. Dolomite is a rock composed primarily of dolomite, and some calcite.

5. Gravels, conglomerate, and breccia: Terms for clasts which are rounded are given below (after Pettijohn, 1957):

\begin{tabular}{|c|c|c|c|}
\hline $\begin{array}{l}\text { Size } \\
(\mathrm{mm})\end{array}$ & $\begin{array}{l}\text { Rounded } \\
\text { Clasts }\end{array}$ & $\begin{array}{l}\text { Unl } \\
\mathrm{Ag}\end{array}$ & $\begin{array}{c}\text { Lithified } \\
\text { Aggregate }\end{array}$ \\
\hline $\begin{array}{l}4-64 \\
2-\quad 4\end{array}$ & $\begin{array}{l}\text { pebble } \\
\text { granule }\end{array}$ & & \\
\hline
\end{tabular}

If the clasts $(2-246 \mathrm{~mm})$ are angular, then the lithified or unlithified rock aggregate will be referred to as breccia.

6. Concretion will refer to a nodular or irregular concentration of various authigenic minerals (barite, pyrite, phosphate, etc).

7. Coal will refer to a dark brown to black, combustible rock of variable physical and chemical composition, produced by the carbonization of vegetable matter.

8. In the core descriptions, we have made some comparison of sedimentary sequences which have grain-size grading and various sedimentary structures to Members A through E described by Bouma (1962). These comparisons simplify what otherwise would be lengthy descriptions, but it is not intended to force a genetic interpretation upon investigators. Bouma's Member A is the lowest of the sequence, and other members sequentially go upward in the geologic section to Member E. Member A: "Graded interval. The bottom part of the layer consists of sand, showing a more or less distinct graded bedding. This grading may be indistinct or even absent if the material is well sorted. The texture of this interval is sandy; sometimes gravel and pebbles may be found. No other characteristic structures are known in this interval."

Member B: "Lower interval of parallel lamination. In this interval a coarse parallel lamination, due to an alternation of more and less clayey sand laminae, predominates. Grading, if present is still going on but lamination predominates. The contact between the graded interval and the lower interval of parallel lamination is generally gradual."

Member C: "Interval of current ripple lamination. This interval consists of current ripples, which are in most cases less than $5 \mathrm{~cm}$ high and not longer than $20 \mathrm{~cm}$. A distinct fore-set lamination is often visible. Sometimes the ripples are more or less convolute. If a pronounced convolute lamination occurs in the layer it is restricted to this interval, in either its lower-, middle-, or upper part or in more than one part." 
Member D: " Upper interval of parallel lamination. An indistinct parallel lamination is characteristic..." "The material consists of a very fine sandy- to silty pelite. Sometimes an upward decrease in sand content is visible. The contact between the ripple interval and this interval is usually distinct."

Member E: "Pelitic interval. The upper interval of the layer shows no visible sedimentary structures. A small upward decrease in grain size and sand content may be found. Often a rapid upward increase in lime content is found. Foraminifera may be found in this pelitic interval. Their number generally increases with increase of lime content and decrease of grain size. The contact between the upper two intervals generally is gradual to very gradual."

\section{Symbols}

Lithologic symbols used in the stratigraphic columns in the site chapters are shown in Figure 4.

\section{Smear Slides}

The lithologic classification of sediments is based on visual estimates of texture and composition in smear slides made aboard ship. These estimates are of areal abundances on the slide and may differ somewhat from the more accurate laboratory analyses of grain size, carbonate content, and mineralogy. Experience has shown that distinctive minor components can be accurately estimated ( 1 or $2 \%$ ), but that an accuracy of 10 per cent for major constituents is rarely attained. Carbonate content is especially difficult to estimate in smear slides, as is the amount of clay. Smear-slide analyses at selected levels as well as averaged analyses for intervals of uniform lithology are given on the core-description sheets. For carbonate content, reference should be made to shipboard carbonate-bomb analyses and shore-based analyses (see below).

\section{CARBONATE BOMB}

Per cent $\mathrm{CaCO}_{3}$ was also determined aboard ship by the Carbonate bomb technique (Muller and Gastner, 1971). In this simple procedure, a sample is powdered and treated with $\mathrm{HCl}$ in a closed cylinder. Any resulting $\mathrm{CO}_{2}$ pressure is proportional to the $\mathrm{CaCO}_{3}$ content of the sample. Application of the calibration factor to the manometer reading $(\times 100)$ yields per cent $\mathrm{CaCO}_{3}$. Error can be as low as 1 per cent for sediments rich in $\mathrm{CaCO}_{3}$, and in general an accuracy of 2 to 5 per cent can be obtained. These data are presented on the coredescription sheets (sample code $=\mathrm{B}$ ).
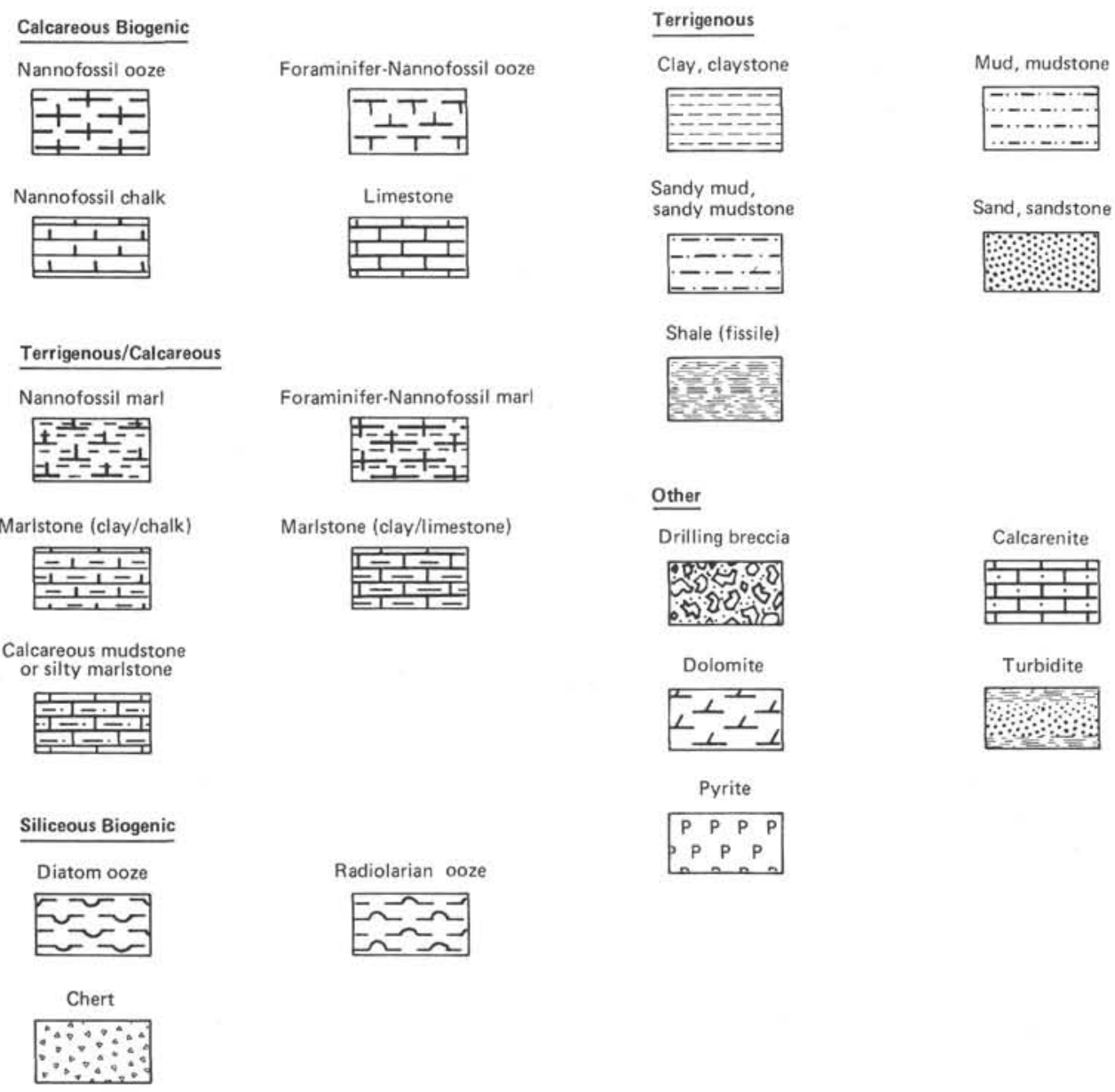

Shale (fissile)

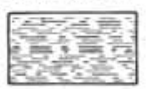

Other
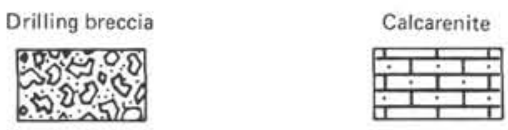

Dolomite

Turbidite
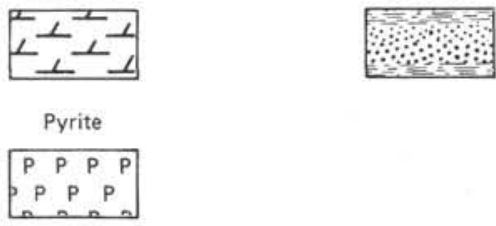

Figure 4. Lithologic symbols. 


\section{CARBON-CARBONATE ANALYSIS}

Following the cruise, sediment samples were analyzed at the DSDP sediment laboratory on a Leco WR-12 Carbon Analyzer. Sample preparation procedures are identical to those used with the old Leco 70 Analyzer, as outlined in Boyce and Bode (1972) and Bode (1973). A discussion of the Leco WR-12 Analyzer can be found in Bode (1978). Accuracy and precision of the results are as follows:

$$
\begin{aligned}
\text { Total carbon } & = \pm 0.3 \% \text { (absolute) } \\
\text { Organic carbon } & = \pm 0.06 \% \text { (absolute) } \\
\mathrm{CaCO}_{3}= & \pm 3 \% \text { (absolute) }
\end{aligned}
$$

The carbon-carbonate data are presented in Appendix 2 , and the data also are presented on the core forms (sample code $=\mathrm{C}$ ).

\section{SEDIMENTARY STRUCTURES}

Megascopic sedimentary structures are apparent in many of the cored sediments. These include primary features such as lamination, graded bedding, and bioturbation, as well as secondary features such as microfaulting. Where it is reasonably certain that these features are not the product of coring disturbance, they are logged graphically in a separate column on the coredescription sheets, utilizing the symbols shown in Figure 5. Caution should be used in drawing conclusions based on the sedimentary structures, because it is often extremely difficult to differentiate between natural structures and those produced by coring.

\section{BIOSTRATIGRAPHY}

The various planktonic-fossil zone schemes used at Sites 415 and 416 are those from (1) Martini (1971) and Gartner (1977) for Cenozoic calcareous nannofossils, (2) Barnard and Hay (1974) for Mesozoic calcareous nannofossils, (3) Blow (1969) and Cita (1975) for Cenozoic planktonic foraminifers, (4) Sliter (this volume) for Mesozoic planktonic foraminifers (a composite zonation developed from recent schemes of van Hinte, 1976a; Premoli Silva and Boersma, 1977; and

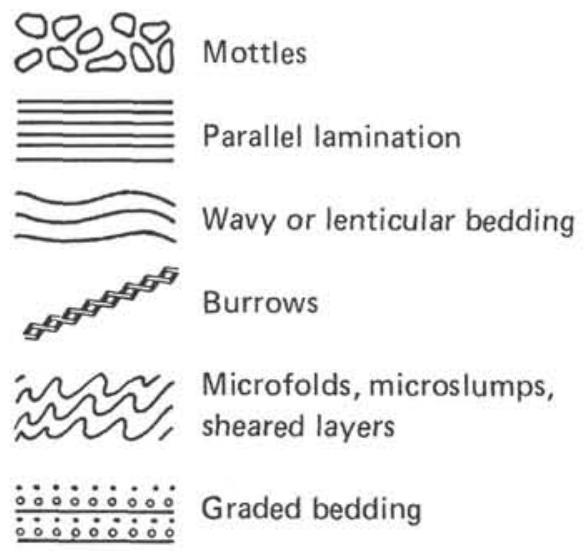

Figure 5. Sedimentary-structure symbols.
Sigal, in press), and (5) from Riedel and Sanfilippo (1978) for radiolarians.

Correlations among these various zone schemes and that of Bukry (1975) applied to the Cenozoic of Site 370, as well as their calibration to the absolute time-scale is shown on Figures 6,7 , and 8 , which were used to estimate sediment-accumulation rates.

\section{CORE DESCRIPTION SHEETS}

The basic lithologic and biostratigraphic data are summarized on core-description sheets (barrel sheets), which are at the end of each site chapter, just ahead of the core photographs. Insofar as possible, the lithologic data for the main lithology are presented in the following order: (1) sediment or rock name; (2) color name and GSA (or Munsell) number; (3) general description of the core, including disturbance, sedimentary structures, and other special features.

At the bottom of the graphic log is a listing of: (1) composition of each smear slide; (2) carbonate-bomb data; (3) carbon-carbonate determinations; (4) grainsize data.

Many cores contain important minor lithologies as well as the major lithology, and descriptive information is included for these wherever possible.

\section{SAFETY AND POLLUTION- PREVENTION PROGRAM}

The program for safety and pollution prevention for Leg 50 consisted of two main parts: site selection and routine shipboard hydrocarbon monitoring. Similar programs have been successfully employed on Legs 47 and 48 , and through a process of trial and experience various procedures were initiated for Leg 50 based on the experiences gained from the previous legs.

The site selection for any hole to be drilled by the Deep Sea Drilling Project is the most important part of the safety and pollution-prevention program.

After a site has been approved by the Safety Panel, if there is a possibility that hydrocarbons in significant quantities may be encountered, then in addition a routine shipboard hydrocarbon-monitoring program is established and all scientists and technicians are familiarized with the procedures.

\section{Routine Shipboard Hydrocarbon Monitoring}

The JOIDES Panel on Pollution Prevention and Safety have prepared a manual in connection with the Deep Sea Drilling Project which is the basis for the safety and pollution-prevention program aboard ship during drilling operations in areas where there is a possibility of encountering significant quantities of hydrocarbons. For Leg 50 the panel also recommended the addition of an experienced petroleum geologist to the scientific staff to assist in the hydrocarbon-monitoring program, and that continuous cores be taken from 1100 meters below the sea floor to total depth for close hydrocarbon monitoring. This depth of 1100 meters was taken from the final depth of Site 370.

Prior to commencement of drilling and coring operations, the JOIDES Manual on Pollution Prevention and 


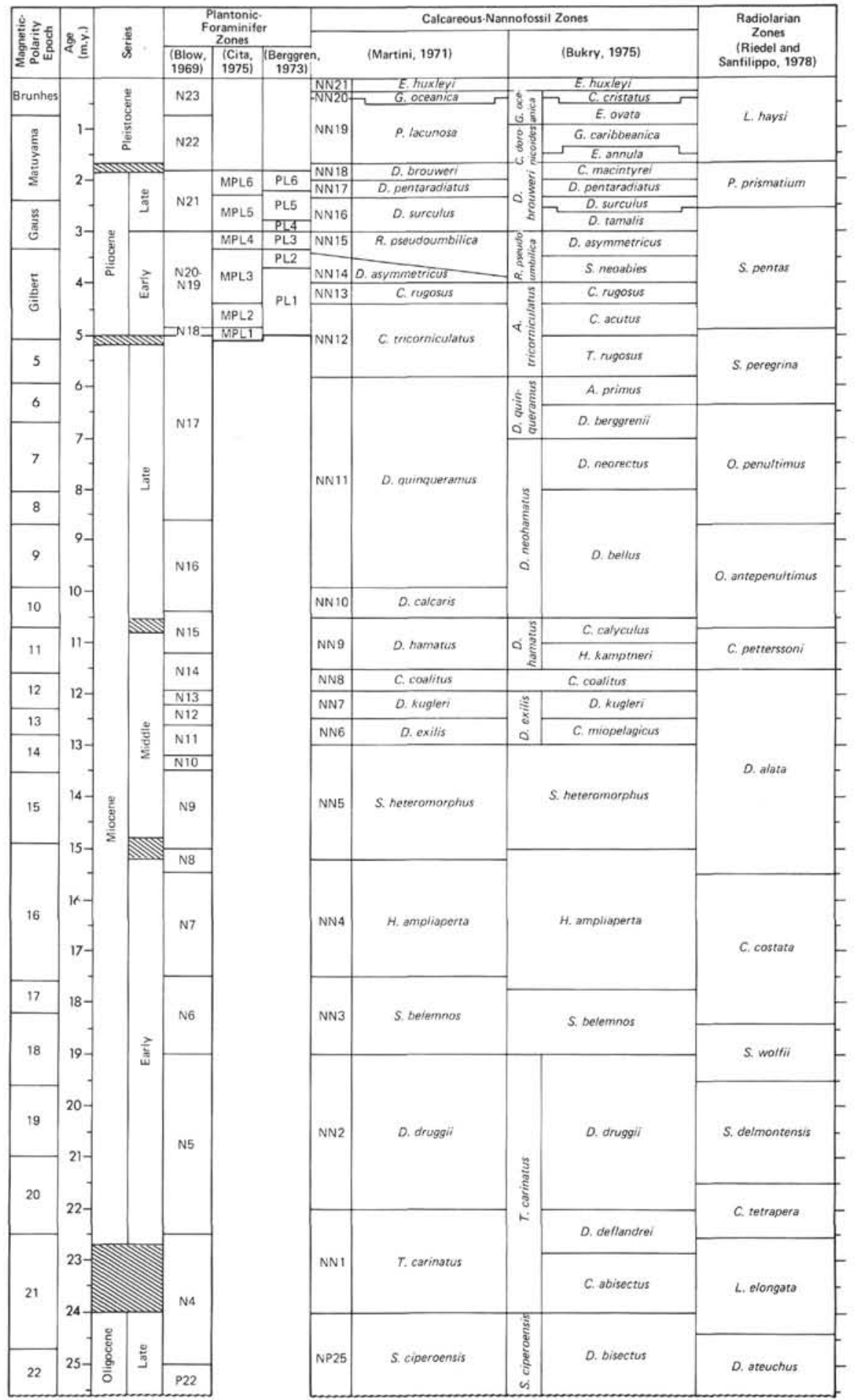

Figure 6. Neogene time scale. The correlation of Blow's (1969) planktonic-foraminiferal zones for tropical regions with those of Martini (1971) for calcareous nannoplankton and the assignment of absolute ages to the zone boundaries are from Berggren (1973), Berggren and van Couvering (1974) and van Couvering and Berggren (1977). The calcareous nannoplankton zonal scheme of Bukry (1975) is correlated with Martini's zonation. The Pliocene planktonic-foraminifer scheme of Berggren (1973) is for the tropical Atlantic and that of Cita (1975) is for the Mediterranean. The ages recognized for the radiolarian zone boundaries of Riedel and Sanfilippo (1978) are those proposed by Theyer and Hammond (1974a, b) and Theyer et. al (1978). The paleomagnetic time-scale is from van Couvering and Berggren (1977) and Theyer and Hammond (1974a, b). 


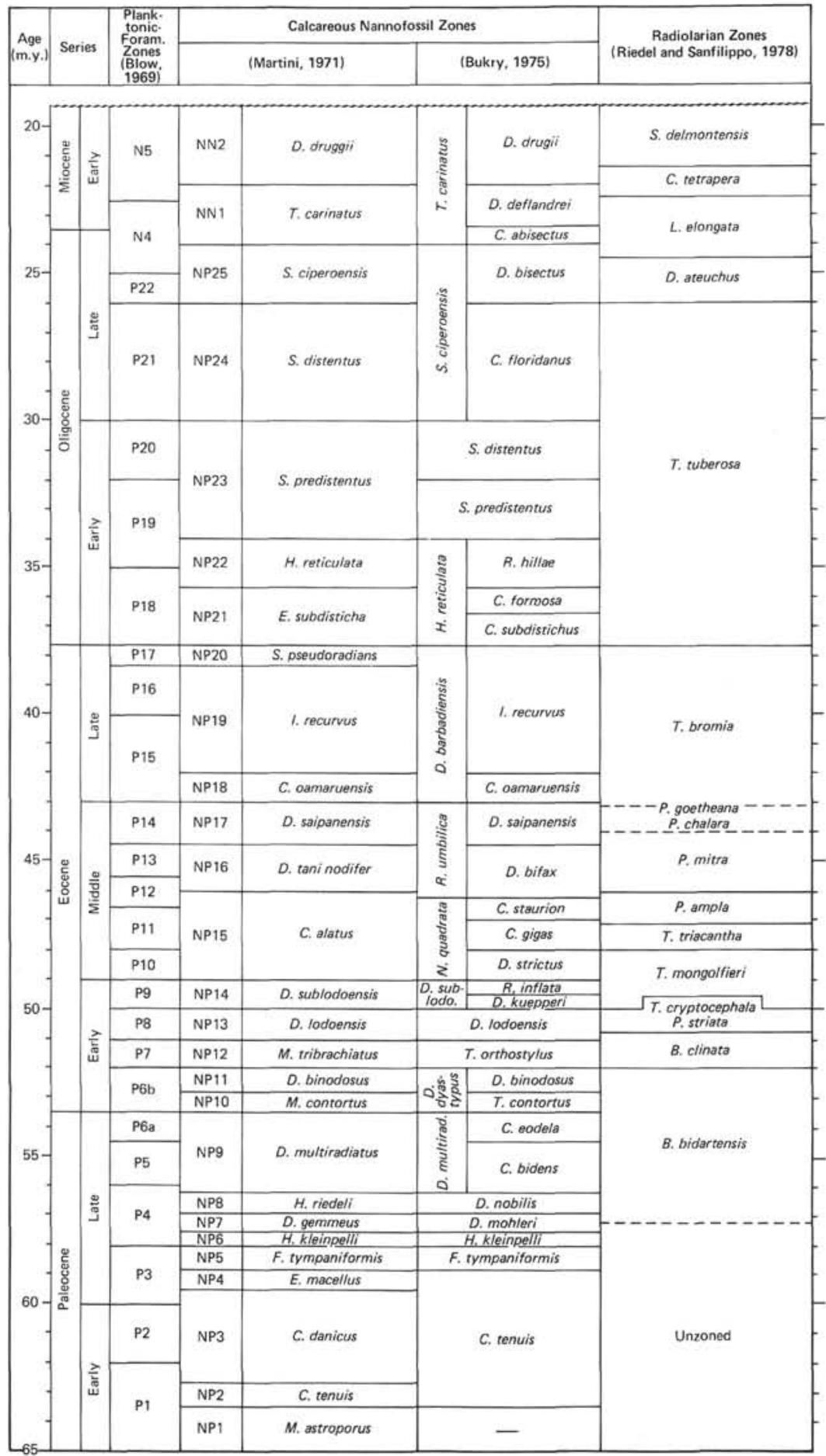

Figure 7. Paleogene time scale (modified from Vincent, 1974).

Safety was circulated to all scientists and technicians for their information. An additional memorandum from the co-chief scientists and shipboard operations manager regarding hydrocarbon safety procedures was sent to all scientists. Meetings were held involving the cochief scientists, operations manager, petroleum geologists, and geochemists to discuss the hydrocarbon-monitoring program and to outline responsibilities and discuss methods.
During the course of drilling and coring operations, routine daily meetings were initiated among the co-chief scientists, operations manager, and the petroleum geologist for briefings on the hydrocarbon monitoring and general discussions and recommendations concerning the safety program.

Generally, the hydrocarbon-monitoring program consisted of three main elements: (1) visual inspection, (2) gas analysis, and (3) pyrolysis. Other factors, such as 


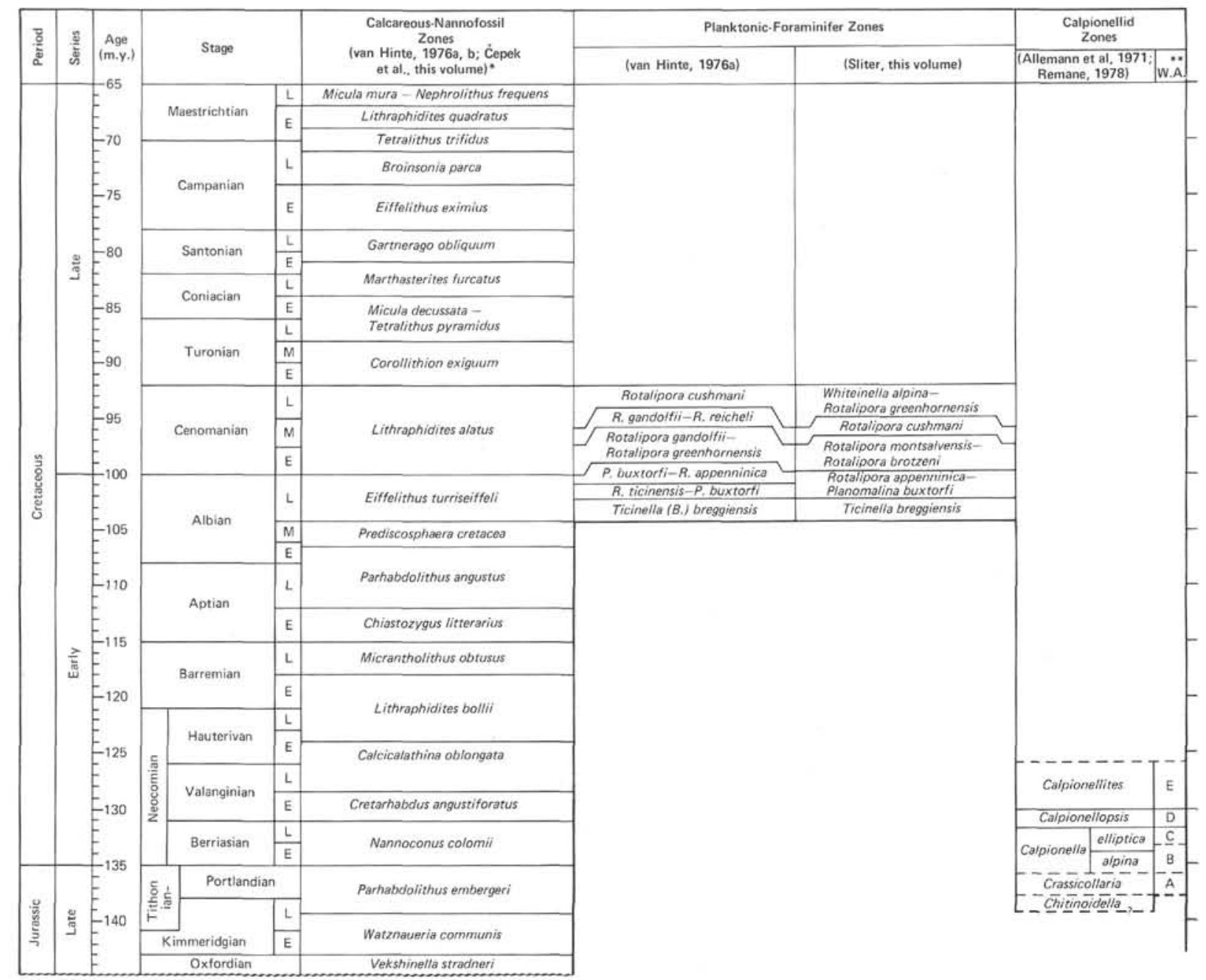

"The zonal scheme of Cepck et a/. (this volume) differs from that of van Hinte (1976a) in that the base of the Lithraphidites alatus zone (as placed here) is defined by the first appearance of $L$. alatus, and thus extends stratigraphically lower than van Hinte's $L$. alatus zone.

“Calpionellid zones for the Western Alps, after Remane.

Figure 8. Cretaceous and latest-Jurassic time scale. The correlations of the calcareous-nannofossil zones with those of van Hinte (1976a) for planktonic foraminifers (only that part of the latter zonation spanning Site 415 faunas is represented here) and with the calpionellid zones from van Hinte (1976a). The assignment of absolute ages to the zone boundaries are from van Hinte $(1976 a, b)$. The planktonic-foraminifer zonal scheme of Sliter (this volume) is correlated to that of van Hinte according to Sliter (this volume).

shale-density measurements and drilling breaks, were taken into account in the overall assessment of the potential danger in encountering significant quantities of hydrocarbons.

\section{Visual Inspection}

As soon as a core was brought to the surface, a small sample was taken off the bottom of the core catcher and checked for fluorescence in the Halliburton ultravioletray box. Samples showing fluorescence were "cut" with chlorothene for determination of hydrocarbons. An additional instrument available for analysis of fluorescence is the Turner Fluorometer, which is useful in detecting levels of fluorescence due to soluble organic compounds. An increase in the fluorometer reading could indicate enrichment in petroleum-type hydrocarbons if a corresponding increase in organic carbon is absent.

After the core was split, it was examined for possible oil staining and checked in the Halliburton UV box if necessary. A visual checklist was employed in describing cores for future reference: the GQF (Gas Quantity Factor):

0 . No noticeable degassing or detectable hydrocarbons in core sample.

1. Detectable hydrocarbon gas but insufficient for reliable analysis. No notable pressure, separating, or bubbling.

2. Sufficient hydrocarbon gas for analysis of core tube samples. Widely scattered bubbling and(or) separation. 
3. "Frying" or "chirping" sounds of gas bleeding from indurated cores. Slight bulging of end caps in storage rack. Minor checking and cracking in softer cores.

4. Pronounced bubbling of gas from core on retrieval. Numerous small separations in soft cores. Strong bulging of end caps.

5. Numerous large separations in soft cores. End caps blown off. Small amounts of soft core extruded from sections on rack.

6. Indications of pressure before opening core barrel. Pronounced expansion of soft core on removal from barrel.

7. Core catcher forcibly blown off.

8. Plug and abandon or set pipe.

This checklist was kept in the core lab, and each core was rated in order by the criteria above. The purpose was to have a record of estimated gas quantity.

\section{Gas Analysis}

Commencing with Core 415A-5, all cores were analyzed for hydrocarbon gas. One sample was taken as soon as the plastic liner containing the core was capped. Likely pockets of gas were sampled, or sometimes the plastic tube was tilted so that all the water would rush toward the bottom and help trap the gas. Another procedure was to allow the core to sit sealed for one or more hours and then take another sample for analysis. This delay might allow more of the heavier gases to escape from the matrix, giving a more meaningful ratio between methane and heavier gases.

After a gas sample was extracted into a vacuvial, it was immediately taken to the geochemistry lab for analysis. First, a 50- $\mu 1$ sample was taken from the vacuvial, and the gas was analyzed by the Carle Gas Chromatograph, which could give percentages of $\mathrm{CH}_{4}$ and $\mathrm{CO}_{2}$ in approximately one to one and a half minutes. This gave a rapid reading on the amount of methane in the gas, which could be related to previous samples for indications of any rapid and large increases in gas concentrations.

A second sample, of $1.0 \mathrm{ml}$, was extracted for analysis by the Hewlett-Packard 5710A Gas Chromatograph, which was installed with a Columbia Scientific Instruments Model CSI 38 Digital Integrator. The HewlettPackard gave readings in parts per million for ethane, propane, butane, and pentane $\left(\mathrm{C}_{2}-\mathrm{C}_{5}\right)$. This analysis, which involves alternating cold and hot baths, takes approximately 15 minutes.

From the results of both chromatographs, the ratio $\mathrm{C}_{1} / \mathrm{C}_{2}+$ was established and plotted graphically against depth. This ratio was used as an indicator of proximity to any potentially dangerous interval of hydrocarbon entrapment. Excessively low values of this ratio would be considered reason for abandoning a site. As mentioned in earlier reports, one would anticipate that this ratio would decrease with depth gradually even where no other evidence for hydrocarbon accumulation exists; therefore, this ratio cannot stand on its own as evidence of proximity to entrapped hydrocarbons.

\section{Pyrolysis}

As was frequently possible, a sample of each core was analyzed for determination of the type of organic material and the ratio of generated hydrocarbons to total hydrocarbons. This combination of data can be used to determine the hydrocarbon-generation potential of sediments, and whether the sediment contains migrated hydrocarbons. Estimates of the "maturation"' of the sediments can be made (i.e., at what depth and temperature hydrocarbon generation would be expected). The device used for pyrolysis determination was a prototype analyzer provided by IFP/FINA. The analyzer quickly and accurately determines four parameters:

1. $S_{1}$, which corresponds to the quantity of hydrocarbons present in the rock.

2. $S_{2}$, which corresponds to the hydrocarbon compounds produced by cracking of the kerogen up to $550^{\circ} \mathrm{C}$.

3. $S_{3}$, which corresponds to the $\mathrm{CO}_{2}$ produced by the pyrolyzed organic matter.

4. The temperature, $T$, corresponding to the maximum of hydrocarbon compounds produced during the pyrolysis of kerogen.

From these parameters one can interpret the results for the following:

1. Identification of the type of organic matter.

2. Petroleum potential of the organic matter.

3. Maturation of the organic matter.

4. Detection of oil shows.

A continual record of these results was maintained and used in conjunction with the gas analysis and visual observations, to evaluate sampled sediments and to predict penetration of a potentially hazardous hydrocarbon accumulation. The routine sample taken for pyrolysis was taken from the core catcher and was analyzed immediately. This "quick" analysis gave a rapid approximation of generated hydrocarbons for safety purposes. This analysis took only about 15 minutes. For the complete pyrolysis analysis of a sample, the sample had to be completely dried and references made. This analysis took approximately $1 \frac{1}{2}$ hours. For the safety and pollution-prevention program, both analyses were taken into account for the overall assessment of the possibility of encountering hydrocarbons in quantity. The "quick" analysis was utilized to assist in evaluating the results of the chromatograph analysis in deciding whether or not to continue coring. If at any time the ratio $\mathrm{C}_{1} / \mathrm{C}_{2}+$ would have been found to corroborate indications of large quantities of generated hydrocarbons from the pyrolysis results, coring operations immediately would have been halted and all available data on geochemical results and knowledge of the anticipated geologic section would have been analyzed before reaching a decision to continue coring or plug and abandon.

\section{GEOCHEMISTRY}

A general chart of shipboard geochemical monitoring and geochemical parameters obtained is shown in Fig- 
ure 9. It includes gas chromatographic analysis of hydrocarbons and a technique for identification of fractions released during pyrolysis of organic matter. In addition, measurements of the organic-carbon and carbonate concentrations, as well as analysis of the chemical composition of the interstitial waters, were carried out.

Gas samples were collected by puncturing the core liner with a special vacutainer adapter.

$\mathrm{CH}_{4}$ and $\mathrm{CO}_{2}$ analyses were carried out by the Carle Model 8000 Gas Chromatograph with cathorometer detector. The column used was $1 / 8$ " O.D. by $5 \mathrm{ft}$ and was filled with 8 per cent Carbowax 1540 on 90 to 100 mesh Anakrom ABS. The column oven temperature was held constant at $40^{\circ} \mathrm{C}$.

$\mathrm{C}_{2}-\mathrm{C}_{5}$ analysis was performed with the Hewlett-Packard Model 5710A Gas Chromatograph with flame-ionization detector and matched-dual-column system working in the compensation mode. Each of the columns consisted of $1 / 8^{\prime \prime}$ by $4 \mathrm{ft}$ spherosil attached to 12 ft by $1 / 8^{\prime \prime}$ of 20 per cent OV101 on Anakrom 11/110 AS. Helium was used as the carrier gas, with a flow rate of $20 \mathrm{~cm}^{3} / \mathrm{min}$. The oven temperature was programmed as follows: initial $T=60^{\circ} \mathrm{C}$ for 4 minutes, then increased to $200^{\circ} \mathrm{C}$ at a rate of $16^{\circ} / \mathrm{min}$ and maintained at $200^{\circ} \mathrm{C}$ for 16 minutes. Air and methane were stripped from the sample before $\mathrm{C}_{2}-\mathrm{C}_{5}$ analysis, by passing the gas through a loop cooled to $-70^{\circ} \mathrm{C}$. The type of vacutainer used shows appreciable background at $\mathrm{C}_{3}, n \mathrm{C}_{4}$ and $n \mathrm{C}_{5}$; the large peak at $\mathrm{C}_{6}$ prevents obtaining useful information about hydrocarbons of the gasoline range.

Organic-carbon content was measured by $\mathrm{CHN}$-analyzer, installed aboard ship. One gram of each sample was acidified with 37 per cent $\mathrm{HCl}$ to estimate the $\mathrm{CaCO}_{3}$ content, using the carbonate-bomb method, as described in a previous report (Initial Reports, Volume 30).

Pyrolysis data were obtained by using an instrument developed by IFP and FINA. About $100 \mathrm{mg}$ of ground and dry sample are weighed and heated from 250 to $550^{\circ} \mathrm{C}$ at a programmed rate of $25^{\circ} \mathrm{C} / \mathrm{min}$. The generated (syngenetic or migrated) hydrocarbons are volatilized at the lower temperature, and potential hydrocarbons are generated at the elevated temperature. $\mathrm{CO}_{2}$ is trapped during the programmed analysis up to $400^{\circ} \mathrm{C}$, and then injected into a column during the decrease of furnace temperature.

Two reference samples and two blanks are regularly analyzed every day. The reference used in this leg is a rock from the Toarcian of the Paris basin (Fecocourt) which has a potential of $60 \mathrm{mg}$ of hydrocarbon per gram of sample, $3.3 \mathrm{mg}$ of $\mathrm{CO}_{2}$ per gram of sample, 10 per cent total organic carbon, and a temperature at the top of the peak $S_{2}$ of $420^{\circ} \mathrm{C}$.

About 20 to $30 \mathrm{mg}$, weighed using the Cahn Model G Gram Electrobalance, of the demineralized sediment was introduced into the Hewlett-Packard Model 185B $\mathrm{CHN}$ Analyzer. This analyzer was operated under the following conditions: oxidation furnace $T=1050^{\circ} \mathrm{C}$; reduction furnace $T=510^{\circ} \mathrm{C}$; column oven $T=$ $100^{\circ} \mathrm{C}$; oven shell $T=80^{\circ} \mathrm{C}$; bridge current $=150$ $\mathrm{mA}$, and carrier gas flow rate $=50 \mathrm{psig}=100 \mathrm{ml} / \mathrm{min}$. Catalyst and boat blanks were made and used in the calculations. Standard runs were made by using the amino acids cystine (NBS \#143b) and acetanilide (NBS \#141b). In all cases the determinations were performed in duplicate.

The values obtained on shipboard are only relative values, because the accurate weighing of standards and samples is impossible. However, these values are reliable within an experimental error of \pm 2 per cent.

Some parameters characteristic of the state of organic matter can be obtained by pyrolysis of organic matter:

1. $S_{1}$, which corresponds to the quantity of hydrocarbons present in the rock and called "generated hydrocarbons."

2. $S_{2}$, which corresponds to the hydrocarbons liberated by kerogen during pyrolysis up to $550^{\circ} \mathrm{C}$ and called "residual potential hydrocarbons."

3. $\mathrm{S}_{3}$, which corresponds to the $\mathrm{CO}_{2}$ produced by the pyrolysis of kerogen.

4. The temperature, $T_{\mathrm{M}}$, corresponding to the top of the $S_{2}$ peak.

From $S_{2}$ and $S_{3}$, it is possible to define the hydrogen and oxygen indexes (in milligrams per gram of organic carbon), which are equivalent to the atomic ratios $\mathrm{H} / \mathrm{C}$ and $\mathrm{O} / \mathrm{C}$. From $S_{1}$ and $S_{2}$, it is possible to calculate the "production index," which is the ratio $S_{1} /\left(S_{1}+S_{2}\right)$. This ratio normally increases with depth.

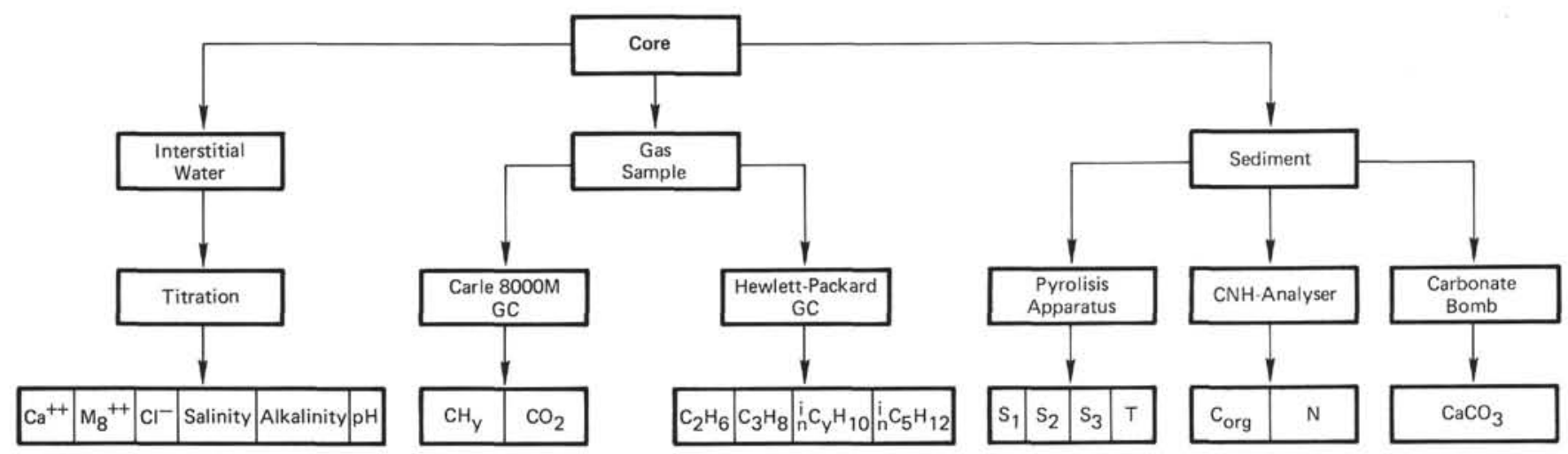

Figure 9. Flow chart of geochemical studies made aboard ship during DSDP Leg 50. 
The maturation steps of source rocks can be determined in various ways:

1. Position of samples on their specific evolution paths on the hydrogen index-oxygen index diagram.

2. Temperature of the top of the peak $S_{2}$; this temperature increases with burial depth, reflecting increasing stability of the organic matter.

3. The evolution of the "production index," which normally increases with depth.

Under standard analysis conditions, the morphology of the peak $S_{2}$ can provide information about the type of organic material.

\section{PHYSICAL PROPERTIES}

Compressional-sound velocity $( \pm 2 \%)$ was measured parallel and perpendicular to bedding on undisturbed samples. From the same sample, a 2-minute Gamma Ray Attenuation Porosity Evaluator (GRAPE) count was taken to calculate wet-bulk density $( \pm 2$ or $3 \%)$, and a wet-water-content sample was also taken. Porosity is determined as the product of the wet-bulk density and wet-water content, with salt corrections applied to the wet-water-content and porosity values. Detailed methods, calculations, and calibrations are discussed in Appendix 3.

The wet sediment or rock cores remained sealed in the original round plastic core liner for at least 4 hours, in order for the samples to approach room temperature. The cores were then split longitudinally, and a sound velocity sample was cut from the split-core. This was an "undisturbed" sample (based on visible undistorted bedding). The sample was cut with a knife or saw, smoothed and then squirted with water, wrapped with a plastic film, and sealed in pint-size plastic container. A wet-sponge was in the container. The sample was always returned to this condition between any physical-property measurements.

Continuous analog-GRAPE wet-bulk density data are presented in this volume. The diameter and its offset from the gamma ray beam were measured, and the material surrounding the solid sediment-rock core was noted. Adjustments and calculations were applied according to the procedures in Boyce (1976). The unadjusted raw data are presented with the fully adjusted data. This presentation will allow investigators to manipulate the data. Detailed equations used and parameters for these equations are discussed in Appendix 3.

Only a few heat-conductivity values are available, because the cores were either disturbed or too hard to run the conductivity needle. The method was set up by Dr. Albert Ericson, using the needle-probe technique of von Herzen and Maxwell (1959).

Only a few measurements of vane shear strength were obtained, because the cores were either disturbed or too hard to perform the test without the sample breaking. A modified Wykeham Farrance Laboratory Vane Apparatus was used (see Appendix 3 for details). The measurement was taken parallel to bedding, with a $1.6 \times 1.6 \mathrm{~cm}$ vane in a split core, the stress applied at 89 degrees per minute. Only undisturbed, clayey-type, fine-grained sediment samples were selected.
A suite of Schlumberger well logs were attempted. These logs include the following Schlumberger tools on a single wire-line lowering or run.

1. Bore-hole-compensated sonic (BHC), caliper (not successful), and gamma ray.

2. Compensated neutron log (CNL), compensated formation-density $\log$ (FDC), and gamma ray. (The upper eccentralizing arm of the FDC-CNL was removed, because it would not fit through the drill pipe.) The only eccentering device available was located at the bottom of the FDC tool. The normal caliper of the FDC tool would not open wide enough to be useful.

3. Dual induction log, Laterolog-8, and gamma ray.

4. High-resolution temperature log (HRT).

5. Gamma ray was run singly in Hole $415 \mathrm{~A}$, with the drill pipe in the hole.

Additional details are given in Appendix 4.

These logs are presented in this volume only at reduced scales. Future investigators may obtain from the DSDP Repository the following:

1. Transparent-ozalid copies of the original raw analog data.

2. Ozalid copies of original raw analog data.

3. Microfilm of the original analog records.

4. Magnetic tapes of the raw original analog data of each $\log$.

5. For each hole: magnetic tapes of sonic, neutron, density, electric, and gamma ray on a single Schlumberger standard library tape (all adjusted to same depth file).

6. A single Schlumberger standard library tape (for each hole) of sonic, electric, density, neutron, and gamma ray, which are all bore hole environment corrected by Schlumberger (see details of assumptions in Appendix 4).

7. The gamma ray log at Site 416 is available on magnetic tape.

8. The Temperature Log at Site 416 has also been digitized by Schlumberger and is also available on magnetic tape.

The data logs published in this volume are the raw uncorrected analog data as obtained at the well site.

The CNL log was saturated (apparent porosity was greater than the upper limit of the tool) at Site 415 and partially at Site 416. In part, this saturation was caused by the lack of a special eccentering arm for the CNL; thus, the CNL was not held against the side of the hole when the hole was vertical, and when the CNL was pulled away from the hole the drill mud may have been "seen" as extra formation porosity.

At Site 416, the FDC-CNL tool's only eccentering arm was broken during the logging run; therefore, the data are questionable.

The caliper (bore-hole diameter) tools were not successful; therefore, no logs have direct bore-hole diameter control to adjust to their data. For simplicity, a 30 -cm (12-inch) diameter is used to correct the logs. A 25.4-cm (10-inch) diameter drill bit was used.

The BHC did not have an eccentralizer; therefore, the sonic data have a significant amount of "noise" (particular high velocity spikes); thus, the condition ren- 
ders the integrated travel time and depth on the log questionable.

\section{REFERENCES}

Allemann, F., Catalano, R., Farès, F., and Remane, J., 1971. Standard calpionellid zonation (upper Tithonian-Valanginian) of the western Mediterranean province. Proc. 2nd Internat. Planktonic Conf. (Roma 1970), v. 2, pp. 1337-1340.

Barnard, T., and Hay, W.W., 1974. On Jurassic coccoliths: a tentative zonation of the Jurassic of southern England and north France. Ecolog. Geol. Helv., v. 67, p. 563-585.

Berggren, W.A., 1973. The Pliocene time-scale: calibration of planktonic foraminiferal and calcareous nannoplankton zones. Nature, v. 243 (5407), p. 391-397.

Berggren, W.A., and van Couvering, J.A., 1974. The late Neogene: biostratigraphy, biochronology and paleoclimatology of the last 15 million years in marine and continental sediments. Palaeogeography., Palaeoecology, Palaeoclimatol., v. 16, p. 1-216.

Blow, W.H., 1969. Late middle Eocene to Recent planktonic foraminiferal biostratigraphy. In Brönnimann, P., and Renz, H.H., (Eds.), Proceedings of the First International Conference on Planktonic Microfossils, Geneva, 1967: Leiden (Brill) pp. 199-421.

Bode, G.W., 1978. Carbon-carbonate determinations by a Leco WR-12 Carbon Analyzer. In Melson, W.G., Rabinowitz, P.O., et al., Initial Reports of the Deep Sea Drilling Project, v. 45: Washington (U. S. Government Printing Office).

1973. Carbon and carbonate analyses-Leg 18. In Kulm, L.D., von Huene, R. et al., Initial Reports of the Deep Sea Drilling Project, v. 18: Washington (U.S. Government Printing Office), pp. 1069-1076.

Bouma, A.H., 1962. Sedimentology of Some Flysch Deposits: New York (Elsevier).

Boyce, R. E., 1972. Grain size analysis, Leg 9. In Hays, H. D. et al. 1972. Initial Reports of the Deep Sea Drilling Project, v. 9: Washington (U. S. Government Printing Office), pp. 779-796.

, 1976. Definitions and laboratory techniques of compressional sound velocity parameters and wet-water content, wet-bulk density, and porosity parameters by gravimetric and gamma ray attenuation techniques. In Schlanger, S. O., Jackson, E. D. et al., Initial Reports of the Deep Sea Drilling Project, v. 33: Washington (U. S. Government Printing Office), pp. 931-958.

Boyce, R.E., and Bode, G.W., 1972. Carbon and carbonate analyses, Leg 9. In Hays, J.D. et al., Initial Reports of the Deep Sea Drilling Project, v. 9: Washington (U.S. Government Printing Office), pp. 797-816.

Bukry, D., 1975. Coccolith and silicoflagellate stratigraphy, northwestern Pacific Ocean, Deep Sea Drilling Project Leg 32. In Larson, R. L., Moberly, R., et al., Initial Reports of the Deep Sea Drilling Project, v. 32: Washington (U. S. Government Printing Office), pp. 677-701.

Cita, M.B., 1975. Studi sul Pliocene e sugli strati di passagio dal Miocene al Pliocene. VIII. Planktonic foraminiferal biozonation of the Mediterranean Pliocene deep sea record-a revision: Riv. Ital. Paleont., v. 81, pp. 527-544.

Gartner, S., 1977. Calcareous nannofossil biostratigraphy and revised zonation of the Pleistocene. Mar. Micropaleont., v. 2, pp. 1-25.

Gealy, E.L., Winterer, E.L., and Moberly, R., 1971. Methods, conventions and general observations. In Winterer, E.L., Riedel, W.R., et al., Initial Reports of the Deep Sea
Drilling Project, v. 7: Washington (U.S. Government Printing Office), pp. 9-26.

Lancelot, Y., Winterer, E.L., Bosellini, A., Melguen, M., Price, I., Schlager, W., Boyce, R.E., Sliter, W., Vincent, E., Cepek, P., Westberg, J., Galimov, E.M., Taguchi, K., Fritz, D., and Boutefeu, A.G., 1977. Documenting early rifting. Geotimes, v. 22, p. 24.

Lancelot, Y., 1973. Chert and silica diagenesis in sediments from the Central Pacific. In Winterer, E.L., Ewing, J.I., et al., Initial Reports of the Deep Sea Drilling Project, v. 17: Washington (U.S. Government Printing Office), pp. 377-405.

Martini, E., 1971. Standard Tertiary and Quaternary calcareous nannoplankton zonation: In Farinacci, A. (Ed.), Proceedings of the Second Planktonic Conference, Rome, 1970: Rome, (Edizioni TecnoScienza), pp. 739-785.

Matthews, T., 1939. Tables of the Velocity of Sound in Pure Water and Sea Water for Use in Echo-Sounding and Sound Ranging: London (Admiralty Hydrogr. Dept.).

Müller, G. and Gastner, M., 1971. The "Karbonate-Bomb," a simple device for the determination of the carbonate content in sediments, soils and other materials, N. Jahrb. Miner., v. 10 , pp. $466-469$.

Pettijohn, F.J., 1957. Sedimentary Rocks: New York (Harper and Row).

Premoli Silva, I., and Boersma, A., 1977. Cretaceous planktonic foraminifers-DSDP Leg 39 (South Atlantic). In Supko, P.R., Perch-Nielsen, K., et al., Initial Reports of the Deep Sea Drilling Project, v. 39: Washington (U.S. Government Printing Office), pp. 615-641.

Remane, J., 1978. Calpionellids. In Haq, B. U., and Boersma, A., (Eds.), Introduction to Marine Micropaleontology: New York (Elsevier), pp. 161-170.

Riedel, W.R., and Sanfilippo, A., 1978. Stratigraphy and evolution of tropical Cenozoic radiolarians. Micropaleont., v. 20 , p. 52 .

Sigal, J., in press. Chronostratigraphy and ecostratigraphy of Cretaceous formations. In Ryan, W.B.F., Sibuet, J.-C., et al., Initial Reports of the Deep Sea Drilling Project, v. 47, Part I: Washington (U.S. Government Printing Office).

Theyer, F. and Hammond, S.R., 1974a. Paleomagnetic polarity sequence and radiolarian zones, Brunhes to polarity epoch 20. Earth Planet. Sci. Lett., v. 22, pp. 307-319.

1974b. Cenozoic magnetic time scale in deep sea cores: completion of the Neogene. Geology, October 1974, pp. 487-492.

Theyer, F., Mato, C. Y., and Hammond, S. R., 1978. Paleomagnetic and geochronologic calibration of latest Oligocene to Pliocene radiolarian events, equatorial Pacific. Mar. Micropaleont., v. 3, pp. 377-395.

van Couvering, J. A., and Berggren, W. A., 1977. Biostratigraphical basis of the Neogene time scale. In Kauffman, E. G., and Hazel, J. E. (Eds.), Concepts and Methods of Biostratigraphy: Stroudsburg (Dowden, Hutchinson and Ross), pp. 283-306.

van Hinte, J.E., 1976a. A Cretaceous time scale. Am. Assoc. Petrol. Geol. Bull., v. 60, pp. 498-516.

1976b. A Cretaceous time scale. Bull. Am Assoc. Petrol. Geol., v. 60, pp. 498-516.

Vincent, E., 1974. Cenozoic planktonic biostratigraphy and paleoceanography of the tropical western Indian Ocean. In Fisher, R.C., Bunce, E.T., et al., Initial Reports of the Deep Sea Drilling Project, v. 24: Washington (U. S. Government Printing Office), pp. 1111-1150.

von Herzen, R.P., and Maxwell, A.E., 1959. The measurement of thermal conductivity of deep-sea sediments by a needle probe method. J. Geophys. Res., v. 64, p. 1557.

Wentworth, C.K., 1922. A scale of grade and class terms of clastic sediments, J. Geol., v. 30, p. 377. 